\title{
RELATING TO THE PAPER ENTITLED “THE SUCCESSFUL APPLICATION OF PREVENTIVE MEASURES AGAINST BERI-BERI," BY DR HAMILTON WRIGHT.
}

LETTER RECEIVED FROM

DR G. A. O. TRAVERS.

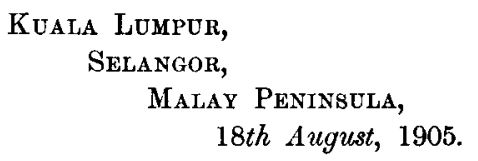

Dear Sir,

I have read with much interest an article on Beri-beri by Dr Hamilton Wright, M.D., C.M. (McGill), in the Journal of Hygiene for April, 1905.

Dr Hamilton Wright, in advancing the theory that Beri-beri is an acute infectious disease with a definite primary lesion, attaches considerable importance to the results of certain recommendations made by him in 1902 with a view to improving the health of the prisoners in the Pudoh Gaol, Kuala Lumpur.

As State Surgeon, Selangor, all practical work in connection with the treatment and care of the prisoners is carried out under my direction. I am therefore able to speak with authority as to the nature and results of any sanitary work done in the Gaol.

I regret to say that Dr Hamilton Wright is under a misapprehension as to the extent of the reforms carried out in the Pudoh Gaol since he completed his observations in 1902.

A special study of Beri-beri having been made in connection with the various outbreaks of this disease at the Pudoh Gaol since 1895 and the results of various observations having from time to time been published, it is, I think, essential, in the interest of medical science, that all statements made in connection with the progress of the disease and measures taken to control it, should be correct in every detail. 
I propose therefore to quote from Dr Hamilton Wright's article, showing in each case what has actually occurred.

"I made in 1902 certain recommendations with reference to the mode of life and hygienic surroundings of the prisoners in the Kuala Lumpur Gaol. More than two years have elapsed since the application of the preventive measures I advocated was begun-time enough in which to test their efficiency."

Dr Hamilton Wright made altogether seventeen recommendations, involving temporary abandonment of the Gaol,structural alterations in the building, demolition of the hospital infirmary, and various alterations in the habits of the prisoners. Of these seventeen recommendations one only, the enlargement of the ventilation spaces in the cells, was carried out, but as none of the altered cells were occupied until the end of January, 1903, by which time Beri-beri had practically disappeared from the Gaol, this can have had little effect in causing the decrease in the number of cases of the disease.

"The various hygienic reforms which came into force between May and September, 1902, were as follows:-

"All prisoners were employed during the greater part of the day at extra-mural work. From September 23rd, 1902, they were accommodated in open-sided sheds during the day."

This arrangement was not suggested by Dr Hamilton Wright but was carried out by Government on the recommendation of the local medical officers, and in view of satisfactory results following similar measures undertaken in 1897 in connection with a severe outbreak of Beri-beri among the prisoners.

"The Gaol has been thoroughly disinfected several times. In February, 1902 , the entire building was washed with $2 \%$ Formalin."

That there has been some mistake as to the extent of the disinfection by Formalin is shown by the following extract taken from a letter from Dr Hamilton Wright to Dr Daniels, Director of the Institute of Medical Research, Kuala Lumpur, dated June 30th, 1904.

"The disinfection carried out in February, 1902, was under my direction and consisted in spraying out the Gaol with a $2 \%$ Formalin solution. I went to India about the middle of the month, after seeing the disinfection well under way. Unfortunately through some misunderstanding, Formalin which lay in the goods shed was not secured and the disinfection came to an untimely end."

Mr Galloway, the Gaoler, who directed the disinfection work, 
informs me that about one-fourth of the Gaol was disinfected with the Formalin solution.

"Under the old régime the prisoners defaecated and urinated in their cells. The provision for the act was most primitive. A small box of sand was provided with a few thin sticks of wood for cleaning the anus. Observation soon showed me that the sticks were of small use and that the fingers were more often employed and afterwards wiped on the floor or on the bedding. It appeared to me that this particular fault in the personal hygiene of the prisoners was the chief factor in the spread of the disease."

The arrangements are in detail as follows :-Each prisoner has a small tin pail fitted with a tin lid in which he defaecates and urinates, he is also provided with a box of dry earth to cover up the faeces in the pail, and with the thin sticks of wood described by Dr Hamilton Wright a small quantity of a solution of Jeyes fluid is placed in each pail when it is put in the cell.

The prisoners are cleanly in their habits, and, during the thirteen years during which I have been connected with the Gaol, I have not seen any case in which the prisoners have used their fingers in the way described.

"In consequence of my recommendation, defaecation by the prisoners in their cells has been stopped."

This is an unfortunate mistake. The prisoners defaecated in their cells as before, and there has been no alteration of any kind in the arrangements made for them in this connection.

"The abolition of Beri-beri in this Gaol has, I consider, been attained by hygienic reforms founded on the view which I have advanced that the infective agent is contained in the excreta of the patient during the acute state of the disease and that infection results from faecal contamination. I would suggest that as an additional preventive measure, the stools of those suffering from acute Beri-beri be disinfected."

For several years the excreta of all patients, including those suffering from Beri-beri, have been passed into a disinfectant solution.

I regret that there should have been any misunderstanding in connection with this subject, more especially as I was under the impression that all had been made clear by a letter from Dr Daniels dated May 2nd, 1904, in which, at Dr Hamilton Wright's own request, complete details of any alterations that have been made in the Gaol or in the habits or the prisoners, were supplied to him. 
I shall be much obliged if you will take such measures as seem to you to be suitable in order to correct the possibly misleading impression conveyed to the medical profession by the article referred to.

I have sent Dr Hamilton Wright a copy of this letter.

Believe me,

Dear Sir,

Yours faithfully,

G. A. O. TRAVERS,

State Surgeon, Selangor.

To THE EDITOR,

The Journal of Hygiene. 